\title{
The gastroprotective effect of Memora nodosa roots against experimental gastric ulcer in mice
}

\author{
DAYANE M. SILVA ${ }^{1}$, JOSÉ L.R. MARTINS ${ }^{1}$, IZIARA F. FLORENTINO ${ }^{1}$, DANILLO R. OLIVEIRA ${ }^{1}$, JAMES \\ O. FAJEMIROYE ${ }^{1}$, LEONICE M.F. TRESNVENZOL ${ }^{2}$, JOSÉ R. PAULA ${ }^{2}$ and ELSON A. COSTA ${ }^{1}$ \\ ${ }^{1}$ Laboratório de Farmacologia de Produtos Naturais, Departamento de Farmacologia, Instituto de Ciências Biológicas, \\ Universidade Federal de Goiás, Campus Samambaia, Rua do Campus, s/n, 74001-970 Goiânia, GO, Brasil \\ ${ }^{2}$ Laboratório de Pesquisa de Produtos Naturais, Departamento de Tecnologia Farmacêutica, Faculdade \\ de Farmácia, Universidade Federal de Goiás, Rua 240, s/n, 74605-220 Goiânia, GO, Brasil
}

Manuscript received on October 7, 2015; accepted for publication on January 6, 2016

\begin{abstract}
Memora nodosa is popularly known as "caroba" and widely found in the Cerrado regions of Brazil. In traditional medicine, the leaves and stems are used for the healing of external ulcer and the roots for abdominal pain. This study investigated the effect of ethanolic roots extract of Memora nodosa (EMN) on the gastric mucosa of mice. In the indomethacin induced gastric ulcer model, the treatments of the animals with EMN at doses of 100, 300 and $1000 \mathrm{mg} / \mathrm{kg}$, p.o., markedly reduced the index of lesions. In the gastric ulcer models induced by ethanol and cold restraint-stress the previous treatment with EMN at dose of 300 $\mathrm{mg} / \mathrm{kg}$ showed $69 \%$ and $43 \%$ of protection, respectively. Seven days after food-restriction, the animals treated with EMN (300 mg/kg p.o.) showed reduction in the index of lesion by $65 \%$ as compared to control group. The intraduodenal administration of EMN $(300 \mathrm{mg} / \mathrm{kg})$ did not alter the gastric acid secretion parameters. The treatment with EMN (300 mg/kg p.o.) did not alter glutathione levels (GSH), but showed an increase of adhered gastric mucus as compared to the control group with lesion. These results showed that EMN has gastroprotective activity probably due with an increase of adhered gastric mucus.
\end{abstract}

Key words: gastric lesion, gastroprotection, medicinal plants, Memora nodosa, mucus, traditional medicine.

\section{INTRODUCTION}

Gastric ulcer is a benign lesion of gastric mucosa that affects a lot of people worldwide. It occurs at a site where the mucosa epithelium is exposed to aggressive factors such as acid and pepsin (Bayir et al. 2006, Bonamin et al. 2014). An important defense is the secretion of a mucus layer that protects gastric epithelial cells retaining the cell surface secreted bicarbonate (Allen and Flemström 2005,

Correspondence to: Dayane Moreira da Silva

E-mail: daymoress@gmail.com
Rodrigues et al. 2012, Gilbert et al. 2015). Therefore, the main therapy for gastric ulcer involves mechanisms of acid suppression and enhanced protection of the gastric mucosa (Deoda et al. 2011).

Efforts are being made in the search for new and suitable antiulcer agents from medicinal plants (Onasanwo et al. 2011, Lakshmi et al. 2010). A recent study conducted by Martins et al. (2015) showed that several plants extracts from Brazilian Cerrado as Ananas ananassoides (Baker) L. B. Sm, Celtis iguanaea (Jacq.) Sargent, Lafoensia pacari A. 
St.-Hil and among others, has been reported to promote antiulcer activity as well as gastroprotection.

Memora nodosa (Silva Manso) Miers (Bignoniaceae) popularly known as "caroba" or "bambuzinho", is native to Brazilian Cerrado (Silva 1998). In the traditional medicine, the leaves and stems of this species are used to treat external ulcers (Siqueira 1988) while the roots are used for treating abdominal pain and scabies (Silva 1998). Phytochemical investigations of $M$. nodosa revealed the presence of flavonoids and saponins in the roots. Besides, in the leaves are present saponins and flavonoids (Siqueira 1988).

The ethanolic extracts of leaves and roots have been reported to possess low toxicity (Tresvenzol et al. 2013). Furthermore, several pharmacological activities have been shown with ethanolic roots extract of this plant including analgesic and antiinflammatory effects (Florentino et al. 2016), antibacterial properties against gram positive bacteria and against Candida albicans fungus (Tresvenzol et al. 2009). In addition, skin wound healing activity was reported (Tresvenzol et al. 2005). Based on the traditional use of this species, this work aims to evaluate the effect of ethanolic extracts from roots of Memora nodosa (EMN) on the gastric mucosa of mice.

\section{MATERIALS AND METHODS}

\section{PLANT MATERIAL}

Roots of Memora nodosa (Silva Manso) Miers (Bignoniaceae) were collected at the Cerrado around Senador Canedo city, Goiás, Brazil (16 $45^{\circ}$ '01's, $49^{\circ} 07^{\prime} 50,6^{\prime \prime} \mathrm{W}$, and height of $717 \mathrm{~m}$ ) and were identified by Prof. Heleno Dias (Institute of Biological Sciences - Federal University of Goiás). A voucher specimen was deposited at the Herbarium of UFG (UFG - 29981).

\section{PREPARATION OF ETHANOLIC EXTRACT}

The samples roots were oven dried with forced ventilation at $40^{\circ} \mathrm{C}$. The material was ground and the root extract was obtained by maceration in $95 \%$ ethanol, followed by concentration on a rotary evaporator at a temperature of $40^{\circ} \mathrm{C}$ (Ferri 1996). The extraction process yielded $4.2 \%$. At the time of use, the EMN was dissolved in filtered water with $2 \%$ Tween $80^{\circledR}$.

\section{ANIMALS}

Adult Swiss mice weighting 30-35 g provided by Central Animal House of Federal University of Goiás (Universidade Federal de Goiás - UFG, Brazil) were used in all experiments. Mice were maintained under standard conditions of temperature $\left(23 \pm 1^{\circ} \mathrm{C}\right)$ and illumination (12h light/12-h dark cycle) with food and water ad libitum. All experiments were performed between 8:00 a.m. and 4:00 p.m. The experimental protocols were approved by the UFG Institutional Ethical Committee (Protocol 104/08).

\section{CHEMICALS AND DRUGS}

Alcian blue 8GX, carbenoxolone, DTNB [5, 5' dithiobis-(2-nitrobenzoic acid)], L-Glutathione reduced, tween $80^{\circledR}$ (all from Sigma Chemical Co., St. Louis, MO, USA ); absolute ethanol, ethylenediaminetetraacetic acid (EDTA), ethyl ether (all from Synth, SP, Brazil), phenolphthalein, trichloroacetic acid, tris. Indomethacin $\left(\right.$ Indocid $\left.^{\circledR}\right)$, sodium hydroxide (all from Merck Sharp \& Dohme, Brazil). Glucose (NEON), magnesium chloride (Vetec), ranitidine (Cloridrato de Ranitidina ${ }^{\circledR}$ Teuto, Brazil). The chemicals used and other solutions were of analytical grade. The substances were prepared just before use.

\section{ANTIULCER STUDIES}

Nonsteroidal anti-inflammatory drug (NSAID)induced gastric ulcer

The gastric lesions were induced as proposed by the Djahanguri (1979) method with some adaptations. The animals were randomly divided into five groups $(n=9)$ and fasted 16 hours with 
free access to glucose water (5\%). The mice were pretreated orally with vehicle $\left(2 \%\right.$ Tween $80^{\circledR}, 10$ $\mathrm{mL} / \mathrm{kg}$ ), EMN at doses 100,300 and $1000 \mathrm{mg} / \mathrm{kg}$ or ranitidine $(50 \mathrm{mg} / \mathrm{kg})$. One hour after pretreatment, the indomethacin $(30 \mathrm{mg} / \mathrm{kg})$ was administered subcutaneous (s.c.). After $6 \mathrm{~h}$ of indomethacin treatment the animals were sacrificed with cervical dislocation and the stomachs were removed for measurement of gastric index of lesion (I.L.). According to Macaúbas et al. (1988), the degree of lesion score were measured. The parameters for determination of index of lesion were color of the mucosa, loss of mucosal folds and mucus, petechial, edema and number of ulcers.

\section{Ethanol induced gastric ulcer}

Gastric lesions were carried out according to adaptation of the method suggested by Robert et al. (1979). After the fasting period (16 h), animals were treated orally with vehicle $\left(2 \%\right.$ Tween $80^{\circledR}$, $10 \mathrm{~mL} / \mathrm{kg}), \mathrm{EMN}(300 \mathrm{mg} / \mathrm{kg}$ ) or carbenoxolone (200 mg/kg). After 60 minutes, gastric ulceration was induced by ethanol solution $(75 \%, 10 \mathrm{~mL} / \mathrm{kg}$ p.o.). One hour after the ethanol administration, the animals were sacrificed, the stomach was removed and opened along the greater curvature. The stomachs were photographed for measurement of the lesion area using CAD software. The lesion area of the gastric mucosa in each animal was calculated and was expressed in percentage (\%) of total area of stomach.

\section{Cold restraint-stress induced gastric ulcer}

The stress was produced by cold restraint of animals, as proposed by Senay and Levine (1967). Animals fasted for $16 \mathrm{~h}$ were treated with vehicle (2\% Tween $\left.80^{\circledR}, 10 \mathrm{~mL} / \mathrm{kg}\right)$, EMN (300 mg/kg) or ranitidine $(50 \mathrm{mg} / \mathrm{kg})$. After $1 \mathrm{~h}$ the animals were immobilized in a cold room at $4{ }^{\circ} \mathrm{C}$. Two hours later, animals were sacrificed and stomach was removed for the determination of index of lesion as described previously.

\section{Food-restriction induced gastric ulcer}

The animals were randomly divided into three groups $(\mathrm{n}=9)$ and subjected to food-restriction for 7 days with free access to water as proposed by the Paré and Houser (1973) method with some modifications. Mice had free access to food twice a day for 60 minutes. After 30 minutes to food access, the animals were orally treated with vehicle $(2 \%$ Tween $\left.80^{\circledR}, 10 \mathrm{~mL} / \mathrm{kg}\right)$, EMN (300 mg/kg) and with a known anti-inflammatory agent (indomethacin 10 $\mathrm{mg} / \mathrm{kg}$ ). $16 \mathrm{~h}$ after the last drug administration, the animals were sacrificed by cervical dislocation and the stomachs were removed for the determination of I.L. as described previously.

\section{GASTROPROTECTIVE MECHANISM}

\section{Determination of the gastric juice parameters}

Using method described by Visscher et al. (1954) with slight modifications, the accumulated gastric contents during 4 hours was evaluated in terms of secreted volume, total acidity and $\mathrm{pH}$. After fasted period (16 h), animals were anesthetized and pylorus ligature was performed. Immediately after pylorus ligature, mice received intraduodenally (i.d.) vehicle $(10 \mathrm{~mL} / \mathrm{kg}), \mathrm{EMN}(300 \mathrm{mg} / \mathrm{kg})$ or ranitidine $(50 \mathrm{mg} / \mathrm{kg})$. Four hours later the animals were sacrificed, the stomach was removed and the luminal content was collected and centrifuged at $2000 \times \mathrm{g}$ for $15 \mathrm{~min}$. The total acid content of gastric secretion was determined by titration to $\mathrm{pH} 7.0$ with $0.01 \mathrm{~N} \mathrm{NaOH}$. The total concentration of acid was expressed as $\left(\mathrm{mEq}\left[\mathrm{H}^{+}\right] / \mathrm{L} / 4 \mathrm{~h}\right)$.

\section{Determination of glutathione levels (GSH) of the gastric mucosa}

Gastric mucosa GSH levels were measured by the method of Sedlak and Lindsay (1968) after ethanol induced gastric lesion. Segment of the glandular region of the stomach was weighted and homogenized in ethylenediaminetetraacetic acid, 
the homogenate was mixed with distilled water and $50 \%$ trichloroacetic acid, and centrifuged. The supernatant $(2 \mathrm{~mL})$ was mixed with Tris buffer and 5, 5' dithiobis-(2-nitrobenzoic acid) was added and the sample was shaken. The absorbance was read at $412 \mathrm{~nm}, 5$ minutes after the DTNB addition.

\section{Determination of adhered mucus to gastric wall}

The determination of mucus content was carried out as described by Corne et al. (1974) after ethanol induced gastric ulcer. Segment of the glandular region of the stomach was weighted and transferred to a test tube containing $7 \mathrm{~mL}$ of $0.1 \%$ Alcian blue. After two consecutive rinses with $5 \mathrm{~mL}$ of sucrose $(0.25 \mathrm{M}), 5 \mathrm{~mL}$ of $\mathrm{MgCl}_{2}(0.5 \mathrm{M})$ was added in each test tube for the extraction of mucus content with the dye. The glandular segment remained in this solution for $2 \mathrm{~h}$, with intermittent agitation. After which $4 \mathrm{~mL}$ of the resultant blue solution was agitated vigorously with $4 \mathrm{~mL}$ of ethyl ether until the formation of an emulsion and was centrifuged at $3600 \times \mathrm{g}$ for $10 \mathrm{~min}$. The absorbance of the supernatant was read at $598 \mathrm{~nm}$. The concentration of Alcian blue was calculated through a calibration curve and the results were expressed in $\mu \mathrm{g}$ Alcian blue/g of glandular tissue.

\section{STATISTICAL ANALYSIS}

The results were expressed as the means \pm standard errors of the mean (SEM). Statistical differences between experimental groups were detected by one-way analysis of variance (ANOVA) followed by post-hoc Student-Newman-Keuls. Values of $\mathrm{p}<$ 0.05 were considered statistically significant. Data were analyzed using GraphPad Prism 5.0 software (San Diego, CA, USA).

\section{RESULTS}

EFFECT OF THE EMN ON NSAID INDUCED GASTRIC ULCER

The gastroprotective effects of EMN on NSAID induced gastric ulcer are shown in Table I. The sub- cutaneous administration of indomethacin showed gastric injury in the control group (12.70 \pm 1.70$)$. EMN 100, 300 and $1000 \mathrm{mg} / \mathrm{kg}$ p.o., showed similarly gastroprotection, reducing I.L. to $7.20 \pm$ $0.35 ; 6.37 \pm 0.41$ and $5.71 \pm 0.47$ respectively $(\mathrm{p}<$ $0.001)$. The group treated with ranitidine decreased I.L. to $6.11 \pm 0.69(\mathrm{p}<0.001)$.

EFFECT OF THE EMN ON ETHANOL AND ON COLD RESTRAINT-STRESS INDUCED GASTRIC ULCER

In both ethanol and cold restraint-stress induced gastric ulcer models, the EMN administration showed significant gastroprotection at doses of 300 $\mathrm{mg} / \mathrm{kg}$. The treatment of mice with ethanol $75 \%$ $(10 \mathrm{~mL} / \mathrm{kg})$ elicited $18.45 \pm 5.50 \%$ of lesion area in stomach of control mice. The extract administrated orally reduced gastric lesions to $5.65 \pm 2.17 \%$ (p $<0.01$ ) on ethanol induced gastric ulcer. Furthermore, carbenoxolone used as positive control reduced ulcerated area to $1.95 \pm 0.85 \%(p<0.001)$. In the cold restraint-stress induced gastric ulcer, control group showed I.L. of $9.10 \pm 1.05$. Pretreatment with EMN (300 mg/kg p.o.) attenuated (I.L. $=5.20 \pm 0.24)$ cold restraint-stress induced injuries $(\mathrm{p}<0.001)$. The treatment with reference drug ranitidine (50 mg/kg p.o.) also decreased the level of gastric damage $(5.11 \pm 0.35, \mathrm{p}<0.001$, Table I).

GASTROPROTECTIVE EFFECT OF EMN ON FOODRESTRICTION INDUCED GASTRIC ULCER

In the present study seven days treatment with EMN (300 mg/kg p.o.) did not elicit gastric damage. The group treated only with vehicle $\left(2 \%\right.$ Tween $80^{\circledR}$, $10 \mathrm{~mL} / \mathrm{kg}$ ) showed index of lesion (I.L.) of 15.01 \pm 2.92 . The chronic treatment with EMN reduced significantly $(5.20 \pm 1.44, \mathrm{p}<0.05)$ the I.L. as compared to control group. The group treated with a known anti-inflammatory agent, indomethacin $10 \mathrm{mg} / \mathrm{kg}$, elicited severe gastric damage (25.71 $\pm 3.16, \mathrm{p}<0.01)$ as compared to control group (Figure 1). 
TABLE I

Effect of ethanolic root extract of Memora nodosa (EMN) in gastric ulcer models induced by NSAID, ethanol and stress in mice.

\begin{tabular}{|c|c|c|c|c|c|}
\hline Experimental models & $\begin{array}{l}\text { Treatment } \\
\text { (p.o.) }\end{array}$ & $\begin{array}{c}\text { Dose } \\
(\mathrm{mg} / \mathrm{kg})\end{array}$ & $\begin{array}{c}\text { I.L. } \\
\text { (index of lesion) }\end{array}$ & $\begin{array}{c}\text { Ulcerated area } \\
(\%)\end{array}$ & $\begin{array}{l}\text { Protection } \\
\quad(\%)\end{array}$ \\
\hline \multirow[t]{5}{*}{ NSAID } & Vehicle & - & $12.70 \pm 1.70$ & - & - \\
\hline & EMN & 100 & $7.20 \pm 0.35^{* * *}$ & - & 43 \\
\hline & EMN & 300 & $6.37 \pm 0.41^{* * *}$ & - & 50 \\
\hline & EMN & 1000 & $5.71 \pm 0.41^{* * *}$ & - & 55 \\
\hline & Ranitidine & 50 & $6.11 \pm 0.69^{* * *}$ & - & 52 \\
\hline \multirow[t]{3}{*}{ Ethanol } & Vehicle & - & - & $18.45 \pm 5.50$ & - \\
\hline & EMN & 300 & - & $5.65 \pm 2.17^{* *}$ & 69 \\
\hline & Carbenoxolone & 200 & - & $1.95 \pm 0.85^{* *}$ & 89 \\
\hline \multirow[t]{3}{*}{ Stress } & Vehicle & - & $9.10 \pm 1.05$ & - & - \\
\hline & EMN & 300 & $5.20 \pm 0.24^{* * *}$ & - & 43 \\
\hline & Ranitidine & 50 & $5.11 \pm 0.35^{* * *}$ & - & 44 \\
\hline
\end{tabular}

Results were expressed as Mean \pm SEM. $n=9$. Data were analyzed by ANOVA followed by Newman-Keuls test. $* * \mathrm{p}<0.01 ; * * \mathrm{p}<0.001$ compared with control group (Vehicle).

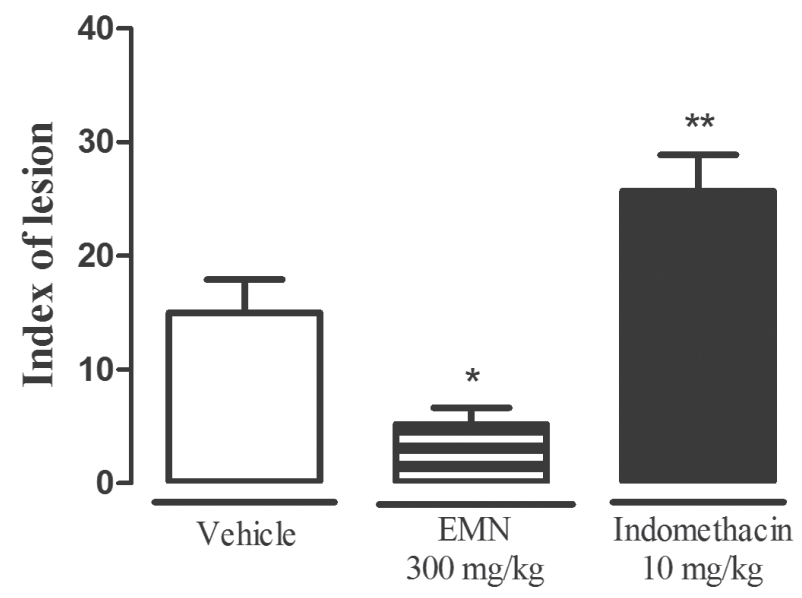

Figure 1 - Effect of ethanolic root extract of Memora nodosa $(\mathrm{EMN})$ on food restriction induced gastric ulcer. Results were expressed as Mean \pm SEM. $n=9$. Data were analyzed by ANOVA followed by Newman-Keuls test. ${ }^{*} \mathrm{p}<0.05 ; *$; $<$ 0.01 compared with control group (Vehicle).

EFFECT OF THE EMN ON GASTRIC JUICE PARAMETERS AFTER PYLORUS LIGATURE

Control group of mice submitted to pylorus ligature during 4 h showed secreted volume of $2.38 \pm 0.07$ $\mathrm{mL}$, total acidity of $4.75 \pm 0.52 \mathrm{mEq}\left[\mathrm{H}^{+}\right] / \mathrm{L}$ and $\mathrm{pH}$ of $3.20 \pm 0.15$. The EMN administered intraduodenally did not alter any of the parameters of gastric acid secretion (Table II). However, ranitidine reduced the volume $(\mathrm{p}<0.05)$, total acidity $(\mathrm{p}<0.01)$ and increased the $\mathrm{pH}(\mathrm{p}<0.01)$ (Table II).

\section{EFFECT OF EMN ON DETERMINATION OF GSH LEVELS IN} THE GASTRIC MUCOSA

The GSH levels were significantly decreased $(128.04 \pm 3.05 \mu \mathrm{g}$ de GSH/g of tissue, $\mathrm{p}<0.01)$ in the control group with lesion (CL) as compared to control group without lesion $(150.41 \pm 5.68 \mu \mathrm{g}$ de $\mathrm{GSH} / \mathrm{g}$ of tissue). Pretreatment of mice with EMN at dose of $300 \mathrm{mg} / \mathrm{kg}$ did not attenuate the ethanol induced depletion of GSH levels (137.22 $\pm 4.15 \mu \mathrm{g}$ de $\mathrm{GSH} / \mathrm{g}$ of tissue). However, the treatment with carbenoxolone increased GSH levels in gastric mucosa $(143.58 \pm 3.80 \mu \mathrm{g}$ de $\mathrm{GSH} / \mathrm{g}$ of tissue, $\mathrm{p}$ $<0.05)$ if compared to control group with lesion (Figure 2).

\section{EFFECT OF EMN ON DETERMINATION OF ADHERED MUCUS TO GASTRIC WALL}

The Alcian blue binding capacity of gastric mucus in the control group with lesion (ethanol $75 \%, 10$ $\mathrm{mL} / \mathrm{kg}$ p.o.) was decreased significantly (29.19 \pm 
TABLE II

Effects of ethanolic root extract of Memora nodosa (EMN) on gastric juice parameters in mice after pylorus ligature.

\begin{tabular}{ccccc}
\hline $\begin{array}{c}\text { Treatment } \\
\text { (intraduodenal) }\end{array}$ & $\begin{array}{c}\text { Dose } \\
(\mathrm{mg} / \mathrm{kg})\end{array}$ & $\begin{array}{c}\text { Gastric juice volume } \\
(\mathrm{mL})\end{array}$ & $\begin{array}{c}\text { Total acidity } \\
\left(\mathrm{mEq}\left[\mathrm{H}^{+}\right] / \mathrm{L} / 4 \mathrm{~h}\right)\end{array}$ & $\mathrm{pH}$ \\
\hline Vehicle & - & $2.38 \pm 0.07$ & $4.75 \pm 0.52$ & $3.20 \pm 0.15$ \\
EMN & 300 & $2.38 \pm 0.06$ & $3.88 \pm 0.66$ & $3.74 \pm 0.31$ \\
Ranitidine & 50 & $2.11 \pm 0.04^{*}$ & $2.16 \pm 0.27^{* *}$ & $4.93 \pm 0.16^{* *}$ \\
\hline
\end{tabular}

Results were expressed as Mean \pm SEM. $n=9$. Data were analyzed by ANOVA followed by Newman-Keuls test. * $p<0.05$; $* * \mathrm{p}<0.01$ compared with control group (Vehicle).

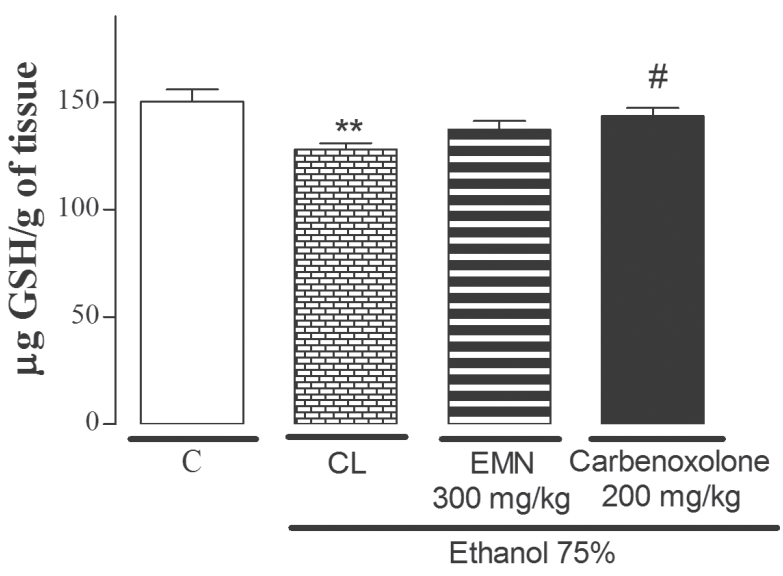

Figure 2 - Effect of ethanolic root extract of Memora nodosa (EMN) on GSH gastric levels. Results were expressed as Mean \pm SEM. $\mathrm{n}=9$. Data were analyzed by ANOVA followed by Newman-Keuls test. $* *$ p $<0.01$ compared with control group (C). ${ }^{\#} \mathrm{p}<0.05$ compared with control group with lesion (CL).

$2.12, \mathrm{p}<0.05)$ as compared to control group without lesion $(38.40 \pm 2.35)$. However, the group of animals with lesion that were pretreated with EMN or carbenoxolone showed enhanced binding capacity of the Alcian blue to gastric wall mucus (Figure $3)$.

\section{DISCUSSION}

The use of NSAIDs is one of the major causes of peptic ulcer. The lesions induced by NSAIDs, such as indomethacin, are related to the inhibition of prostaglandin synthesis with consequent reduction of mucus and bicarbonate and also, with a significant increase in gastric secretion due the prostaglandin $\left(\mathrm{PGE}_{2}\right)$ exerts an inhibitory action on gastric secretion stimulated by $\mathrm{H}_{2}$ receptors. Making

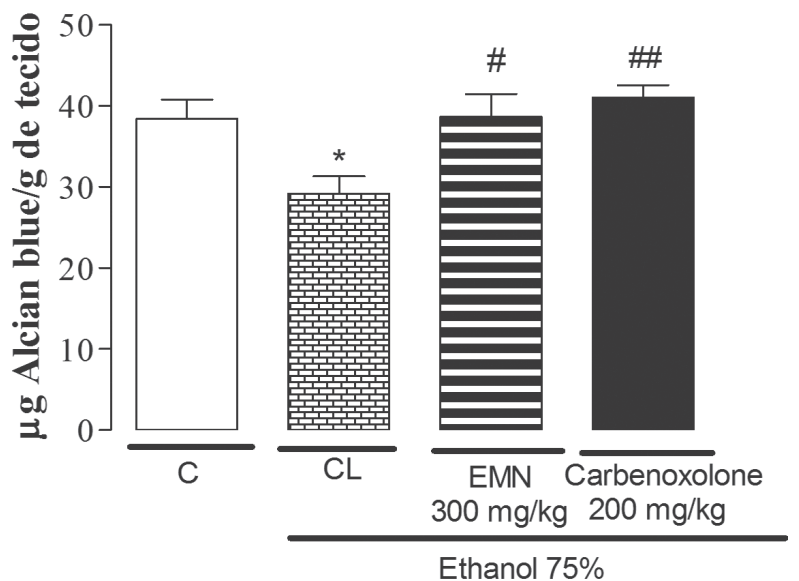

Figure 3 - Effect of ethanolic root extract of Memora nodosa (EMN) on gastric mucus content. Results were expressed as Mean \pm SEM. $n=9$. Data were analyzed by ANOVA followed by Newman-Keuls test. ${ }^{*} \mathrm{p}<0.05$ compared with control group (C). ${ }^{\#} \mathrm{p}<0.05$; ${ }^{\# \#} \mathrm{p}<0.01$ compared with control group with lesion (CL).

this method very sensitive to the gastroprotective effect of $\mathrm{H}_{2}$ receptor antagonists, such as ranitidine (Feldman and Colturi 1984, Rainsford 1992). In the first acute study we screened EMN at doses of 100,300 and $1000 \mathrm{mg} / \mathrm{kg}$ (p.o.) in indomethacin induced gastric ulcer. All EMN doses used in this model showed a significant decrease in the index of lesion. This result suggests the involvement of prostaglandins and gastric mucus in the gastroprotective effect of the $M$. nodosa extract. From our preliminary acute study we found dose at $300 \mathrm{mg} /$ $\mathrm{kg}$ for further studies.

In ethanol induced gastric ulcer, treatment of the animals with the extract $(300 \mathrm{mg} / \mathrm{kg}$ p.o.) or carbenoxolone $(200 \mathrm{mg} / \mathrm{kg}$ p.o.) reduced the ulcerated area by 69 and $89 \%$ respectively. The 
intense damage caused by ethanol, results in the appearance of hemorrhagic gastric lesions and reduction in the mucus content (Pan et al. 2008, Nordin et al. 2014).

Stress has significant contribution in the pathophysiology of gastric ulcer and can promote damage through acid secretion, activation of hypothalamus-pituitary-adrenal axis, proliferation of pro-inflammatory cytokines and decrease in local blood flow. Such lesions can be detected after short exposure of animals to a stressful situation (Morsy et al. 2012).

Ethanol and stress cause gastric injury through inflammatory and oxidative processes by generation of reactive oxygen species (ROS) who are directly involved with damage of cell membranes (Hernández-Muñoz et al. 2000, Amirshahrokhi and Khalili 2015). Studies have demonstrate that carbenoxolone protects gastric mucosa of ethanol and stress induced lesions since it is able to prevent the reduction of mucus caused by this harmful agent and by the increase of glutathione and other antioxidants agents (Rozza et al. 2014). The reduction of gastric lesions in ethanol and stress induced gastric ulcers, could be suggestive of the involvement of cytoprotective factors, such as an increase in gastric mucus in the effect of EMN.

Following gastroprotective activity of the extract in acute models, gastroprotective activity of EMN was studied in a chronic model induced by food-restriction. This method is characterized by a reduction in the protection of the mucosa due the food-restriction and due to the stress induced in this model. This model was chosen because it is a chronic model and depending on the design of the treatment can be also evaluated a healing activity. Previous work revealed anti-inflammatory activity of ethanolic roots extract of Memora nodosa (Florentino et al. 2016). However, studies have shown that chronic use of some anti-inflammatory agents can elicit gastric damage, including gastric ulcer (Kwiecién et al. 2015). Although the exact anti-in- flammatory mechanisms of EMN are still unclear, we hypothesized that the extract with anti-inflammatory property should demonstrate gastric injury in mice after chronic administration. However, the EMN did not elicit gastric damage as compared to control group. The group treated with a known anti-inflammatory (indomethacin) showed increase in the index of lesion induced by food-restriction.

In order to elucidate the possible antisecretory mechanism of the Memora nodosa, pylorus ligature was carried out. Acid secretion is regulated by hormonal, paracrine and neural factors represented by gastrin, histamine and acetylcholine respectively (Schubert 2014). Compounds that can inhibit any of these factors could substantially lower the acid content. The administration of the EMN intraduodenally did not alter the parameters evaluated $(\mathrm{pH}$, volume and total acidity), thereby demonstrating that EMN do not directly participate in the modulation of acid secretion.

Oxidative stress has been associated with the pathogenicity of different diseases, including peptic ulcer (Fahami et al. 2005). Glutathione plays a central role in the defense against oxidative stress, and is responsible for the maintenance of gastric integrity. Glutathione in its reduced form (GSH) protects cells through removal of reactive metabolites or conjugation (Cnubben et al. 2001). The lesions caused by ethanol administration reduced GSH. Pre-treatment with the EMN did not increase the levels of these groups. Hence, the gastroprotective mechanism of EMN seems unrelated with GSH levels.

In the ethanol induced gastric lesion, EMN $(300 \mathrm{mg} / \mathrm{kg})$ demonstrate an increase of adhered gastric mucus as compared to control group with lesion, suggesting that mucus levels may be an important mechanism of its gastric cytoprotection. The gastric mucus barrier and bicarbonate are the first line defense of the mucosa whose secretion is stimulated by prostaglandins, mainly $\mathrm{PGE}_{2}$ (Allen and Flemström 2005). It is secreted by epithelial cells in the superficial gastric mucosa and acts as a 
protective barrier against acid, luminal pepsin, necrotizing agents such as ethanol and also maintains the $\mathrm{pH}$ gradient near neutral (Bighetti et al. 2002, Laine et al. 2008).

The results of the present study demonstrate that oral treatment with the EMN reduced gastric ulcer in different gastric ulcer models. The effect of EMN seems to be associated with an increase of adhered gastric mucus. Further studies are needed to isolate and purify the active principle (s) involved in the antiulcer activity of this plant.

\section{CONCLUSIONS}

The present work revealed the antiulcer activity of ethanolic roots extract of Memora nodosa in mice. The treatment with this extract reduced ulcer formation in different gastric ulcer models induced by indomethacin, ethanol, stress and food restriction probably due to the increase of adhered gastric mucus. However, future pharmacological and phytochemicals researches will be focused on the investigation of the underlying mechanism and the secondary metabolites responsible by this action.

\section{ACKNOWLEDGMENTS}

The authors are grateful to Coordenação de Aperfeiçoamento de Pessoal de Nível Superior (CAPES), Conselho Nacional de Desenvolvimento Científico e Tecnológico (CNPq) and Fundação de Amparo à Pesquisa do Estado de Goiás (FAPEG) for financial support.

\section{RESUMO}

Memora nodosa, popularmente conhecida como "caroba", é amplamente encontrada em regiões de Cerrado no Brasil. Na Medicina Tradicional, as folhas e as raízes são utilizadas para o tratamento de úlceras externas e as raízes para dores abdominais. O presente trabalho objetivou avaliar o efeito do extrato etanólico das raízes da Memora nodosa (EMN) na mucosa gástrica de camundongos. No modelo de úlcera gástrica induzida por indometacina, o tratamento dos animais com EMN nas doses de 100, 300 e $1000 \mathrm{mg} / \mathrm{kg}$, v.o., foi capaz de reduzir o índice de lesão. Nos modelos de úlcera gástrica induzida por etanol e por estresse o tratamento com EMN na dose de $300 \mathrm{mg} / \mathrm{kg}$ foi capaz de proteger a mucosa gástrica em 69 e 43\%, respectivamente. Após sete dias de restrição alimentar, os animais tratados com EMN (300 mg/kg v.o.) mostrou uma redução no índice de lesão de $65 \%$ quando comparado ao grupo controle. A administração intraduodenal de EMN $(300 \mathrm{mg} / \mathrm{kg})$ não alterou os parâmetros de secreção ácida gástrica. $\mathrm{O}$ tratamento com EMN (300 mg/kg v.o.) não alterou os níveis de glutationa (GSH), mas foi capaz de aumentar o muco gástrico aderido, quando comparado ao grupo controle lesado. Esses resultados mostram que o EMN possui atividade gastroprotetora provavelmente devido ao aumento de muco gástrico aderido à mucosa gástrica.

Palavras-chave: lesão gástrica, gastroproteção, plantas medicinais, Memora nodosa, muco, Medicina Tradicional.

\section{REFERENCES}

ALLEN A AND FLEMSTRÖM G. 2005. Gastroduodenal mucus bicarbonate barrier: protection against acid and pepsin. Am J Physiol 288: C1-C19.

AMIRSHAHROKHI K AND KHALILI AR. 2015. The effect of thalidomide on ethanol-induced gastric mucosal damage in mice: involvement of inflammatory cytokines and nitric oxide. Chem-Biol Interact 225: 63-69.

BAYIR Y, OdABASOGLU F, CAKIR A, ASLAN A, SUlEYMAN H, HALiCI M AND KAZAZ C. 2006. The inhibition of gastric mucosal lesion, oxidative stress and neutrophilinfiltration in rats by the lichen constituent diffractaic acid. Phytomedicine 13: 584-590.

Bighetti AE, Antônio MA And CARVAlho JA. 2002. Regulação e modulação da secreção gástrica. J Med Sci 11(Suppl.1): 55-60.

BONAMIM F ET AL. 2014. The effect of a minor constituent of essential oil from Citrus aurantium: The role of $\beta$-myrcene in preventing peptic ulcer disease. Chem-Biol Interact 212: 11-19.

CNUBBEN NHP, RIETJENS IMCM, WORTELBOER H, VAN ZANDEN J AND VAN BLADEREN P. 2001. The interplay of glutathione-related processes in antioxidant defense. Environ Toxicol Phar 100: 141-152.

CORNE SJ, MORRISEY SM AND WOODS RJ. 1974. A method for the quantitative estimation of gastric barrier mucus. J Physiol-London 242: 116-117.

DEODA RS, KUMAR D AND BHUJBAL SS. 2011. Gastroprotective effect of Rubia cordifolia Linn. on aspirin plus 
pylorus-ligated ulcer. J Evid Based Complementary Altern Med 2011: 5.

DJAHANGURI B. 1979. The production of acute gastric ulceration by indomethacin in the rat. Scand J Gastroentero 4: 265.

FAHAMI NAM, ISMAIL NM AND KADIR KBA. 2005. Phytonutrients: experimental effects on gastric lesions in rats exposed to acute repetitive restraint stress. Nutr Food Sci 35(Suppl.6): 403-409.

FELDMAN M AND COLTURI TJ. 1984. Effect of indomethacin on gastric acid and bicarbonate secretion in humans. Gastroenterology 87: 1339-1343.

FERRI PH. 1996. Química de produtos naturais: métodos gerais. In: Di Stasi LC (Ed), Plantas Medicinais: arte e ciência, Editora da Universidade Estadual Paulista, São Paulo, p. 129-156.

FLORENTINO IF, Silva DPB, GALDINO PM, LinO RC, MARTINS JLR, Silva DM, PAUla JR, TRESVEnZOL LMF AND COSTA EA. 2016. Antinociceptive and antiinflammatory effects of Memora nodosa and allantoin in mice. J Ethnopharmacol 186: 298-304.

GilberT A, HAUBERline MDM, BREUIL DFR, William YN AND ALBERT K. 2015. Antiulcerogenic and Antiulcer Activities of Dissotis thollonii (Melastomataceae) leaves in rats. Int J Pharm Pharm Sci 7(Suppl.8): 562-569.

HERNÁNDEZ-MuÑOZ R, MONTIEL-RUíz C AND VÁZQUEZMARTínez O. 2000. Gastric Mucosal Cell Proliferation in Ethanol-Induced Chronic Mucosal Injury Is Related to Oxidative Stress and Lipid Peroxidation in Rats. Lab Invest 80(Suppl.8): 1161-1169.

KWIECIÉN S, MAGIEROWSKA K, ŚLIWOWSKi Z, WÓJCIK D, MAgierowski M AND BRzozowsKi T. 2015. New insight into the mechanisms of gastroduodenal injury induced by nonsteroidal anti-inflammatory drugs: practical implications. Pol Arch Med Wewn 122(Suppl.3): 191-198.

LAINE L, TAKEUCHI K AND TARNAWSKI A. 2008. Gastric Mucosal Defense and Cytoprotection: Bench to Bedside. Gastroenterology 135: 41-60.

LAKShMi V, Singh N, ShrivastVa S, Mishra SK, DHARMANI P AND Mishra V AND PALIT G. 2010. Gedunin and photogedunin of Xylocarpus granatum show significant anti-secretory effects and protect the gastric mucosa of peptic ulcer in rats. Phytomedicine 17: 569-574.

MACAÚBAS CIP, OLIVEIRA MGM, FORMIGONI MLOS, SilveirA FILHO NS AND CARLINI EA. 1988. Estudo de eventual ação antiúlcera gástrica do bálsamo (Sedum sp.), folha-da-fortuna (Bryophyllum calycinum), couve (Brassica oleracea) e da espinheira-santa (Maytenus ilicifolia) em ratos. In: Carlini EA (Org), Estudo de ação antiúlcera gástrica de plantas brasileiras (Maytenus ilicifolia "espinheira-santa" e outras). Brasília, Ministério da Saúde, CEME, p. 5-20.

MARTINS JLR, RODRIGUES OR, SOUSA FB, FAJEMIROYE JO, GALDINO PM, FLORENTINO IF AND COSTA EA. 2015.
Medicinal species with gastroprotective activity found in the Brazilian Cerrado. Fund Clin Pharmacol 29: 238-251.

Morsy MA, HeEBA GH, ABDELWAHAB SA AND RofAEIL RR. 2012. Protective effects of nebivolol against cold restraint stress-induced gastric ulcer in rats: Role of NO, HO-1, and COX-1,2. Nitric Oxide 27(Suppl.2): 117-122.

NORDIN ET AL. 2014. Anti-Ulcerogenic Effect of Methanolic Extracts from Enicosanthellum pulchrum (King) Heusden against Ethanol-Induced Acute Gastric Lesion in Animal Models. PLoS ONE 9(Suppl.11): e111925.

OnASANwo SA, Singh N, Olaleye SB AND PALit G. 2011. Anti-ulcerogenic and proton pump $\left(\mathrm{H}^{+}, \mathrm{K}^{+}\right.$ATPase $)$ inhibitory activity of Kolaviron from Garcinia kola Heckel in rodents. Indian J Exp Biol 49: 461-468.

PAN JS, HE SZ, XU HZ, ZhAN XJ, YANG XN, XIAO HM, SHI HX AND REN JL. 2008. Oxidative stress disturbs energy metabolism of mitochondria in ethanol- induced gastric mucosa injury. World J Gastroenterol 14: 5857-5867.

PARÉ WP AND HOUSER VP. 1973. Activity and food-restriction effects on gastric glandular lesions in the rat: The activitystress ulcer. Bull Psychon Soc 2(Suppl.4): 213-214.

RAINSFORD KD. 1992. Mechanisms of NSAID-induced ulcerogenesis: structural properties of drugs, focus on the microvascular factors, and novel approaches for gastrointestinal protection. Acta Physiol Hun 80(1-4): 23 28.

ROBERT A, NEZAMIS JE, LANCASTER C AND HANCHAR AJ. 1979. Cytoprotection by prostaglandins in rats: Prevention of gastric necrosis produced by alcohol, $\mathrm{HCl}, \mathrm{NaOH}$, hypertonic $\mathrm{NaCl}$ and termal injury. Gastroenterology 77: 433-443.

RODRIGUES PA, MORAIS SM, SOUZA CM, MAGALHÃES DV, VIEIRA IGP, ANDRADE GM, RAO VS AND SANTOS FA. 2012. Gastroprotective effect of Byrsonima sericea DC leaf extract against ethanol-induced gastric injury and its possible mechanisms of action. An Acad Bras Cienc 84: 113-122.

ROZZA AL, FARIA FM, BRITO ARS AND PELLIZZON CH. 2014. The gastroprotective effect of menthol:Involvement of anti-apoptotic, antioxidant and anti-inflammatory activities. PLoS ONE 9: e86686.

SCHUBERT ML. 2014. Gastric secretion. Curr Opin Gastroenterol 30(Suppl.6): 578-582.

SEDLAK J AND LINDSAY RH. 1968. Estimation of total protein bound and nonprotein sulfhydril groups in tissues with Ellman's reagent. Anal Biochem 25: 192-205.

SENAY SE AND LEVINE RJ. 1967. Synergism between cold and restraint for rapid production of stress ulcer in rats. Proc Soc Exp Biol Med 124: 1221-1223.

SILVA SR. 1998. Plantas do Cerrado utilizadas pelas comunidades da região do Grande Sertão Veredas. Brasília, Fundação Pro-Natureza-FUNATURA, 109 p.

SIQUEIRA JC. 1988. Plantas medicinais: identificação e uso das espécies do cerrado. São Paulo, Loyola, 40 p. 
Tresvenzol LMF, FiUZA TS, PIMENTA FC, ZATTA DT, BARA MTF, FERRI PH, LIMA ABM AND PAULA JR. 2009. Chemical composition of essential oil and antimicrobial activity of Memora nodosa (Bignoniaceae). Lat Am J Pharm 28: 53-59.

TRESVENZOL LMF, PARENTE LML, LINO JUNIOR RS, FIUZA TS, BARA MTF, CUNHA LC, LAXOR LP, Miguel MP AND PAULA JR. 2013. Avaliação da toxicidade aguda e da atividade cicatrizante dos extratos etanólicos das folhas e raízes da Memora nodosa (Silva Manso) Miers (Bignoniaceae). Rev Bras Plant Med 15: 423-430.

TRESVENZOL LMF, QUEIROZ DC, REZENDE RC, NASCIMENTO TL, ROSA VS AND PAULA JR. 2005. Estudo farmacognóstico da Memora nodosa (Manso) Miers. Rev Eletronica Farm 2: 221-223.

VISSCHER FE, SEAY PH, TAZELAAR JR AP, VELDKAMP W AND VANDER BROOK MJ. 1954. Pharmacology of pamine bromide. J Pharmacol Exp Ther 110(Suppl.2): 188-204. 